\title{
Asiantuntijuutta tukevaa johtamista
}

\author{
Erkki Takatalo (2010). Toimiva työyhteisö. Näkökulmia opistotyön kehittämiseen.
}

Kansanvalistusseura. ISBN 978-951-9140-56-8

VAPAAN SIVISTYSTYÖN yhteisjärjestön Toimiva työyhteisö -valmennuksen tavoitteena on ollut kehittää vapaan sivistystyön oppilaitosten henkilöstön toimintavalmiuksia ja yhteistyötä muutostilanteessa. Valmennusta on toteutettu vuosina 2004-2009 ja mukana on ollut noin 30 työyhteisöä tai niiden yhteenliittymää, 580 henkilöä ja 55 oppilaitosta.

Valmennuksen perusajatuksia ja kymmenen valmennusesimerkkiä on koottu pieneksi ja painavaksi kirjaksi, jonka ohjelman suunnittelija ja toteuttaja Erkki Takatalo on kirjoittanut. Takatalo toimii koulutuspäällikkönä Jyväskylän yliopistossa, erikoisalanaan johtaminen.

Kirjan viesti - verrattuna moniin maailmantuskaa poteviin vapaan sivistystyön teksteihin - on häkellyttävä: valmennusohjelma tai kirja ei analysoi vapaan sivis- tystyön tehtävää, vaikuttavuutta tai merkitystä. Kirjan keskeinen viesti on, että opistojen omat työntekijät kehittävät ja luovat kehittämisen rakenteet ja käytännöt itse. Tärkeintä on dialoginen vuorovaikutus ja oman työn avoin tutkiminen yhdessä. Valmennus koskee muutostilanteita ja koska muutosta ei voi hallita, valmennuksen tavoite on ollut auttaa kohtaamaan muutoksen tuomaa epävarmuutta. Valmennus on luottanut mukana oleviin ihmisiin.

Kirja jakautuu työn ja työyhteisön osa-alueita valottavaan teoreettiseen ja käytännön hankkeita esittelevään osaan. Teoreettinen osa on otteeltaan praktinen ja tavoitteena on selvästi auttaa arjen paineissa kieppuvaa ihmistä näkemään kehittämismahdollisuuksia. Teoriaosa on nimetty Osaamisalueiksi ja kehittämiskohteiksi ja alaluvut käsittelevät johtamista, viestintää, yhteistyötä, työtyytyväisyyttä ja hyvinvointia sekä muutostyötä. Tarkastelun taustalla on prosessijaottelu perustehtävään ja sen tukitoimintoihin eli edellä mainittuihin alalukujen teemoihin. Kirja tarjoaa jokaiseen osaamisalueeseen ja kehittämiskohteeseen sekä näkökulman että metodin toiminnan kehittämiseen. Metodeihin on purettu auki valmennusohjelman teemat ja lukija voi aavistaa, miten metodia on käytetty käytännön valmennustyössä.

Teoriaosan painavin osa käsittelee johtamista, strategian luomista ja osaamisen kehittämistä. Myös alaistaitojen (muualla samasta käytetään myös käsitettä 'työyhteisötaidot') merkitystä käsitellään. Takatalo innostaa rehtoreita ottamaan työhönsä tutkivan otteen, johon voi käyttää esimerkiksi kokemuksellisen oppimi- 
sen kehää: ongelman määrittely asiantuntijoiden kanssa, ongelman luonteen arviointi, ongelman käsittely parhailla tavoilla ja uuden mallin kehittäminen ja kokeilu.

\section{YHDESSÄ OSAAVAN}

\section{HENKILÖSTÖN KANSSA}

Takatalon mukaan tutkimuksellinen ote sopii erityisen hyvin vapaan sivistystyön johtamiseen ja suunnitteluun, koska opetuksen tavoitteena on antaa eväitä ennakoimattoman tulevaisuuden kohtaamiseen ja ainoa tapa silloin on vahvistaa toimijoissa itsessään asiantuntijuutta ja tulevaisuuden "osaamista". Samaa tavoitetta palvelee myös strategian laatimisen ohjeistus: tulevaisuuskuvan muodostus ja matkan teon opastus osaavan henkilöstön kanssa. Työntekijöiden osaamisen tueksi voidaan käyttää sekä osaamiskartoitusta että kehityskeskusteluja.

Johtamisosioon olisin kaivannut kansalaisopistojen tuntiopettajien suuren määrän merkitystä niin oppilaitosrakenteen kuin myös johtamisen näkökulmista. Samoin tuntiopettajien oma näkökulma työyhteisön jäseninä tarvitsisi oman esille nostonsa ja valmennusohjelmansa. Tuntiopettajat kyllä mainitaan valmennusohjelmien yhteydessä, mutta heidän roolinsa tai opetustyön pohjautuminen pitkälti tuntiopetukseen ei nouse teemana esille.

\section{SISÄISEN VIESTINNÄN}

\section{RAKENNUSAINEKSIA}

Sisäisen viestinnän kuvauksessa Takatalo lainaa Jaana Venkulalta auttavan tiedon viittä e:tä, joita vas- ten kannattaa peilata omaa tapaansa viestiä. E:t ovat episteeminen, emootiot, empiria, etiikka ja esteettisyys. Kun ottaa nämä huomioon, voi saada viestit perille toivomallaan tavalla. Takatalo avaa myös keskustelun ja dialogin eroja, joista jälkimmäinen on syvenevää ja yhdessä rakentavaa "mielekkäitä rajapintoja hakemalla”. Kirja esittelee itselleni uuden ja hyvin käyttökelpoiselta tuntuvan yhteisöälykkyyskäsitteen.

Työn ja työyhteisötason rinnalle on tuotu yksilön, työntekijän toiminta, jonka tilanneanalyysiin ja kehittämiseen käytetään kuntopiiriä. Ammatillinen, henkinen, sosiaalinen ja fyysinen kunto kuvataan lyhyesti teoriajakson alussa, mutta sitten ne jäävät takaalalle kirjan keskittyessä työn yhteisöllisempiin puoliin.

Valmennusesimerkeistä kolme kertoo kansanopistoista ja seitsemän kansalaisopistoista. Kansanopistot kehittivät omaa oppilaitostaan sellaisenaan, kun taas kansalaisopistokentällä useassa hankkeessa näkyi eri puolilla maata käynnissä oleva muutos opistojen yhdistämisinä ja alueellisena verkottumisena. Henkilöstömäärän pienuus kuvaa vapaan sivistystyön kenttää. Seitsemän opiston verkottumishankkeessa oli mukana 30 henkilöä ja he olivat kaikki päätoimiset työntekijät näissä opistoissa. Esimerkit ovat todentuntuisia ja niissä yhdistyy teoriaosuuden monet puolet. Oppilaitokset ovat rohkeita, kun ovat antaneet kokemuksensa jaettavaksi muille.

\section{TYÖN ILO HEIJASTUU} OPISKELIJOIHIN ASTI

Kirjan läpi kulkee tärkeä viesti siitä, että kun vapaa sivistystyö haluaa tuoda iloa ja oppimisen kokemuksia opiskelijoilleen, on sen omien toimijoiden hyvä tuntea työn iloa ja imua. Kirjassa määritellään opetuksen ydinteemoiksi ihmis-, tieto- ja oppimisnäkemykset ja kehotetaan itse kutakin niitä pohtimaan omalla kohdallaan. On myös mahdollista, että kaikki eivät jaa samalla tavoin humanistista ihmiskuvaa ja oppimisnäkemystä, vaan todellisuus on tätä värikkäämpi. Voi olla, että vapaan sivistystyön idealistinen tehtävä tuottaa huonosti voivia ihmisiä, jos itse voi huonosti samalla, kun työn annettuna lähtökohtaoletuksena on hyvä ja kehittyvä ihminen.

Omassa työssäni niin Helsingin työväenopiston johtavana rehtorina kuin aiemmissakin tehtävissäni olen kohdannut monet kirjan esittelemistä näkökulmista. Kokemukseni perusteella uskallan sanoa, että kirja tarjoaa aitoja aineksia työn ja työyhteisön kehittämiseen. Kirja on kartta, jossa monenlaiset polut tarjoavat reittejä vaihtelevaan maastoon ja erilaisiin keleihin. Perillekin voi päästä tai ainakin eteenpäin kurkistamaan seuraavan kukkulan taakse. Suosittelen.

\section{Taina Törmä \\ rehtori \\ Helsingin suomenkielinen \\ työväenopisto}

